\title{
Shrinkage perceptions and smart growth strategies for the municipalities of Portugal
}

\author{
Thomas Panagopoulos and Ana Paula Barreira
}

CIEO, University of Algarve, Campus de Gambelas, 8005-139, Faro, Portugal

September 2011

\begin{abstract}
:
In the last decade, several Portuguese municipalities have faced population decline. This paper systematises the most implemented strategies by the Portuguese governments and identifies their results in dealing with population decline. Based on a survey of the most important newspapers and municipality websites, and by using economic and demographic annual data for 10 years (1999-2008), it was found that the majority of the municipalities have implemented strategies of "smart growth" and "smart shrinkage", while the others have presented a misperception of shrinkage. The resilience capability of each municipality, in the adaption of the activities of primary and secondary sectors into the tertiary sector, was identified as an important factor for the success of smart growth strategies.
\end{abstract}




\section{Introduction}

Many regions in Europe are being confronted with population decline. For instance, according to the United Nations (2008) World Population Prospects Database, Bulgaria, Poland, Germany, Portugal and Italy will lose, respectively, 28, 16, 14, 7 and 5 per cent of the population by 2050, compared with the 2010 figures. Causes and consequences emerging from shrinking are being identified in recent studies (Frank, 2004; Muller and Siedentop, 2004). However, the study of the implications of shrinkage for local governments and municipalities are rare. Koziol's (2004) study is one of the few exceptions.

This paper focuses on shrinkage, evaluated primarily by the decrease in population numbers in Portuguese municipalities, and subsequently by the changes that are observed on the labour force, real estate value, and other municipal amenities, but without establishing any causal relationships among them. The primary variable of analysis is the demographic trend. Population decline is frequently used as the main indicator in the research of shrinkage (see Rink et al., 2009), although the term cannot be confined merely to a population problem since it embraces other issues like housing vacancies, economic decline or land misallocation.

The municipality is used as the territorial unit to evaluate shrinkage in Portugal since, in this country, local governments act at the municipal level; the Portuguese mainland does not have regional governments, or urban governments. More than half of the Portuguese mainland municipalities have population decline problems. Portuguese local governments have reasons to be concerned with population decline as the major financing sources are dependent on the number of inhabitants. In this sense, local governments tend to encourage growth. Shrinkage in Portugal has different causes, but we look particularly at those occurring in rural- and medium-sized municipalities.

The main goal of this paper is to systematise the most implemented strategies by Portuguese central and local governments and identify their results in dealing with population decline. 
From this point, to the best of our knowledge, this is the first paper. This paper provides answers to the following questions for the case of Portugal: 1) What are the adopted smart growth and smart shrinkage strategies? 2) Do these strategies conform to international experiences? 3) Have these implemented strategies helped in reversing the shrinkage process?

Based on a survey of the most important Portuguese newspapers and municipality websites and by using the annual socioeconomic data for 10 years (1999-2008), we found that the main strategies adopted to deal with shrinkage in Portugal are promotion of marriage, attraction of secondary education students, maintenance of health care services and creation of new employment opportunities.

Our analysis shows that only a smart growth strategy that relies on a multi-task approach generates sustainable results. Those results are closely related with the capacity of the municipality to adapt those economic sectors that face a decrease in demand because of the globalisation process into new economic sectors that provide competitive advantages.

Although the majority of the municipalities are adopting strategies that seek growth, we also found a small number of municipalities that are implementing strategies that show acceptance of the shrinkage phenomenon, thus developing smart shrinkage strategies. In such municipalities, the goal is not to reverse the decline of the population but to guarantee a certain quality of life standard that ensures the maintenance of the municipality as a pleasant place to live. Finally, we discuss the implications that emerge from the lack of connection between the interventions of the local and central governments.

\section{Problem definition}

This paper deals with two approaches toward solving the problem of shrinkage: smart growth and smart decline strategies. In order to position the problem, we review the literature for 
concepts, present the relationship between shrinkage and some research fields, and review international experiences on coping with the issue.

\subsection{Definition of concepts}

The term smart growth that became popular in USA during the 90's when it became a part of Maryland's legislation means providing financial and planning incentives to combat sprawl and to promote compact development (Daniels, 2001; Gabriel et al., 2006). Downs (2001) offers 14 potential elements of smart growth that comprehend relatively differentiated aspects, from regional tax base sharing to compact and mixed-use development to preserving open space or create walkable neighbourhoods. Beside those aspects, smart growth also refers to fostering distinctive, attractive communities with a strong sense of place, and strengthening of development towards existing communities. The smart growth concept used in this paper follows these last aspects closely in the sense that political actions aim to improve the quality of life in municipalities, to remain attractive for the population, and thus sustaining or even reversing the loss of residents. In fact, Caragliu et al. (2009) believe, in the context of a city, that a public intervention is "smart" when investments in human and social capital promote sustainable economic growth and a high quality of life, with a wise management of natural resources.

The term smart shrink emerges in Germany after the collapse of the Berlin Wall when several eastern cities registered a profound population decline (Oswald, 2005). According to this author, just as growth was not always experienced as a positive process (pollution, house shortage, etc.), shrinkage will not always be experienced as negative in long-term sustainable development. Pallagst et al. (2009) refer that shrinking places face challenges such as become more productive and ecologically sustainable, even with fewer people, and a shrink smart process is achieved when those challenges are accomplished. Popper and Popper (2002) propose a new model of smart decline that mimics smart growth and suggest that planning for less demand - fewer people, buildings and land uses - ensures good life conditions. 


\subsection{Research fields}

The questions on population decline are the topics of research in political economy and planning. However, since basic assumptions are diverse, practical implications are often controversial. As societies evolve, the living standards improve and increase the households' requirement for facilities and services offered by local governments. This requirement is a consequence of the replacement of mass production for more flexible post-Fordist arrangements, resulting in life-style changes in which the society demands gradually more consumption of services (Lovering, 2009). Under growth, this demand could be reached since increased economic activity generates more taxes and enables more resources for financing many local public goods. Local governments are prepared to deal with a growth scenario that brings more job opportunities and inhabitants to the municipalities, but are less prepared to live with shrinkage. Using a political perspective, Beauregard (2003) points out that given the criticism from voters, policymakers fear to espouse shrinkage in order to avoid their political suicide. Public decisions taken by bureaucrats, who are concerned with their chance for reelection, do not help in this matter (Grant, 2009).

According to Swope (2006), most politicians are not comfortable accepting a decline and try to manage it with revitalization plans. Even urban planners are not well equipped to handle shrinkage. Literature on planning is fundamentally oriented toward growth and on how to manage it (see Daniels, 2001; Szold and Carbonell, 2002), although shrinkage is part of the normal change cycle that many cities have faced since historic times (Van den Berg et al., 1982). According to Muller and Siedentop (2004) planning tools are prone to new development of land, new construction and more public infrastructure as an incentive to attract economic activity, while the required public intervention in opposition should favour the recycling of land and buildings or the adaptation of public facilities to meet the residents' changing needs. In fact, planning for shrinkage is fundamentally different from planning for growth (Rybczynski and Linneman, 1999). 


\subsection{International experience of strategies conforming to shrinkage}

Glaeser and Gyourko (2005) state that growth typically results in rapid population increases with stable housing values, while decline is associated with slow population decline with rapid property devaluation. The most widespread strategies to deal with shrinkage emerge from the American and German experiences that were confronted with a huge vacant housing problem. The specificities of the two countries are well documented in Großmann et al. (2008). According to Pallagst (2008), in the United States, political intervention is more in affinity with growth where shrinkage is seen as a kind of stigma and as such, revitalisation actions are focused on city centres. Papers by Schilling (2008) and Schwarz (2008) show the transition processes faced by Buffalo and Cleveland due the loss of population.

Local authorities of Germany had to rethink on land occupation by promoting policies toward the revitalisation of city centres, consequently deactivating underused public services, and demolishing vacancies. Glock and Häußermann (2004) analyse the implementation of such policies for the eastern cities of Germany. Other works look at particular German cities and policies implemented therein such as Lötscher et al. (2004), Wiechmann (2008) and Lange (2008) for, respectively, Eisenhüttenstadt, Dresden and Leipzig.

The government initiatives in Germany are also in accordance with the concern for altering the physical footprint of the cities, turning for instance existing brown fields into green spaces. Another common local policy followed in Germany is the transformation of declining cities into "creative cities". Shapiro (2006) found a strong positive correlation between human capital (measured as the share of the adult population with a college degree) and the growth in the quality of life, with the population growth of cities. 
3. Empirical application to the Portuguese municipalities

\subsection{Phenomenon description and research framework}

Portugal is a country where political decisions are mainly concentrated at the central level, which is usually identified by international institutions, such as the IMF as a unitary country, meaning that the political levels below the central government are not entirely free to set policies. In Portuguese mainland', there are only two political levels: a central government and several local governments, and the latter governed by an elected mayor (President of the Municipal Chamber) and his/her executives. Local governments in Portugal are identified as Municipalities," and annual socioeconomic data for them are available making relevant statistical analyses of shrinkage at that level possible. Data at sub-unit levels such as cities or even smaller geographical places are available at Census data, made available only at each ten years. Municipalities comprehend urban and rural areas, being almost the only exceptions Lisbon, the capital, and Oporto, the second most important municipality, classified as a whole as an urban areas.

Portugal comprehends 308 municipalities of which 278 of them are in the mainland. Of these, 121 have been systematically shrinking between 1999 and 2008 and account for $10.26 \%$ decrease of the inhabitants. This number includes Lisbon and Oporto. Other 37 municipalities have population loss in the last 5 years. Summing up, the reduction of inhabitants occurs in $57 \%$ of the Portuguese municipalities.

Not all Portuguese local governments are located in the cities. Some of them are located in villages in the case of the municipality not having a city. In accordance, Portugal has three causes for municipal shrinkage: 1) lack of an urban rehabilitation policy in big cities causing an increase of rental estate prices; 2 ) sudden end of the most important economic activity in the municipalities with medium-sized cities; and 3) constant decrease of the primary and secondary sectors in rural municipalities. 
Figure 1 emphasizes that the declining population is mostly located in the interior parts of the country, while the coastal municipalities are growing, excluding Lisbon and Oporto.

\section{(Insert Figure 1 here)}

Figure 2 shows the shrinking and growing municipalities: Municipalities with a declining population arranged between municipalities with a permanent and severe process of shrinkage (population loss above $10 \%$ during the decade), municipalities with a permanent but slight shrinkage process (population loss below 10\%) and municipalities with a recent shrinkage process (during the last five years of the analysed period). An aggregate picture of the Portuguese population path between the declining and growing municipalities is also presented.

\section{(Insert Figure 2 here)}

Portuguese experience in dealing with shrinkage is different from the German or American experiences described in subsection 2.3 and differs from the set of policy recommendations identified by the ongoing EU $7^{\text {th }}$ framework project Shrinksmart (2009). International experience has been focused on the urbanization process leading, for instance, to building demolition policies. In Portugal, there is no integrated urban rehabilitation policy, a consistent heritage conservation policy, or even a specific policy to deal, for instance, with vacancies.

Having established that the goal is to identify the implemented strategies by the Portuguese municipalities to deal with population decline and evaluate their results, by departing from section 2 and considering the specificities of Portugal, we establish the following hypothesis to be tested in the following subsection:

$\mathrm{H} 1$ : Municipalities that succeed in reversing the shrinkage process are those evidencing an ability to replace declining economic activities. 
H2: Most local governments prefer to implement smart growth strategies by avoiding or delaying the acceptance of the shrinkage problem.

H3: Implemented smart shrinkage strategies are oriented to the maintenance of already available public services rather than to downsizing policies.

In this paper, population is the nuclear variable of analysis. The other considered demographic variables are population below 15 years, population over 65 years and births. Social variables, such as number of marriages, number of students in secondary schools, and number of doctors per 1000 inhabitants were also considered. Economic variables include the number of employees in the establishments of the municipality and their respective disaggregation by economic sector: primary, secondary and tertiary, and the real value of sold property.

\subsection{Implemented policies by municipalities with severe shrinkage}

We begin by analysing those municipalities whose populations have been continually declining. In a subset of 35 municipalities with the highest population contraction observed $(>10 \%) 34$ registered a decrease of the elderly in the second half of the decade. This decrease in the elderly is a symptom of permanent shrinkage that reflects the absence of generational replacement, since the theory predicts that young people are the first to abandon places causing an increase of the elderly inhabitants.

Departing from a survey of Portuguese newspapers and municipal websites, we systematise the most preferred policies promoted by local governments to cope with shrinkage. Four types of local strategies followed by the municipalities were identified. Strategies include incentives to marriage, increase in the number of secondary schools, increase in medical care per capita, and local employment promotion. 


\subsubsection{Policies promoting marriage}

Under this strategy, local governments by offering houses or other residential advantages to young couples, try to attract new inhabitants to the municipalities. Table 1 shows municipalities with a significant increase in the number of marriages. This policy however is not accompanied in most cases by other policies, including policies to promote employment. Therefore, the majority of the municipalities continue to face a decrease in the number of births. Lisbon, the capital city, is an exception because women from neighbouring municipalities have their babies in the central hospital maternities.

(Insert Table 1 here)

Figure 3 shows the municipalities that have registered a significant increase in the number of marriages. The number of marriages has increased predominantly in the rural municipalities because of an active policy of the local governments to capture new households to their municipalities. In the second map of Figure 3, the special emphasis on marriage dynamics for the South of Portugal is shown.

\section{(Insert Figure 3 here)}

Alcoutim and Ourique are municipalities located in the South of Portugal where the number of marriages has increased significantly. Despite the aggressive policy of these municipalities, the failure is evident. Even Alcoutim in which the number of marriages has increased exponentially, the birth numbers have decreased owing to the lack of jobs opportunities.

Boticas, Vinhais and Marvão, despite the local governments' stimulation of the number of marriages are unable to retain inhabitants, as these municipalities did not generate employment. Almeida is another case in which the increase in the number of marriages does not invert the population decline because of unemployment. Industrial employment here is in the decline and most of the jobs offered in the primary sector are often seasonal inhibiting permanent residence. 


\subsubsection{Policies to attract secondary students}

Access to elementary and high-performing public schools emerges as a device in preventing population exit and guarantees equal opportunities. This kind of policy is a way of promoting social and economic justice, thus ensuring regional equity and smart growth (Blackwell and Fox, 2004). In Portugal, the central government defines the school network and decides where secondary schools should be built. However, local governments play a managing role on secondary schools and are interested in attracting students to the municipality with the expectation that they will opt to reside there in the future.

This kind of policy intends to increase the municipal educational level and therefore promotes employment of the qualified. With this purpose, some municipalities negotiate with the central government for the maintenance of or the building of secondary schools. The goal of attracting students is achieved in nine municipalities reported in Table 2 . The two major municipalities of Lisbon and Oporto were excluded from this analysis as the number of students in secondary education there is related to the fact that parents travel to those municipalities for work and bring their children with them. The employment profile in the remaining seven municipalities that show an increase of students in secondary education has been evolved to absorb people with secondary or even graduate degrees. Despite not solving the problem of population decline, such a strategy can promote the increase of wealth creation.

(Insert Table 2 here)

Attracting secondary school students generates employment in several municipalities. However, this is not sufficient to retain inhabitants. In the analysed cases, restructuring of the employment profile with the replacement of primary and secondary sector jobs by the tertiary sector jobs are not enough to invert the decrease in population. 


\subsubsection{Policies aiming the maintenance of health care services}

This strategy aims at ensuring more health care for the inhabitants to prevent them from departing from a municipality. Carlsen et al. (2009) have shown that an average satisfaction level of health care in municipalities makes them more attractive to households. As young families decline, a municipality will be increasingly composed of aged individuals, who increasingly request the maintenance of spending on health care (Mading, 2004). This kind of policy is seen as reflecting a shrinkage smart approach.

Although health care policy in Portugal is a responsibility of the central government, the local governments have to be consulted while considering any downsizing policy. Some local governments force the maintenance of primary health care facilities, such as health centres, in an attempt to deal with population decline. This behaviour is in accordance with the findings of Sedlacek (2007) that suggest local public goods are deliberately oversized in many municipalities in order to make them attractive to households. However, this strategy does not generate new avenues of employment, as can be seen in Table 3.

A health care services maintenance policy generates a conflict between the central and local governments, since the former plans to close some of the facilities based on the small number of patients, a position that is opposed by the latter. Differences in the positions occur because central government pays the cost of providing health care services while the local governments have an incentive to align with the population that prefers to maintain the facilities.

\section{(Insert Table 3 here)}

\subsubsection{Employment oriented policies}

This strategy aims to give residents a reason to stay in a municipality by ensuring employment opportunities to the inhabitants. Public policies intending to facilitate the location of economic activity and hence, control the abandonment of the inhabitants are sensitive to the supported 
sector. Table 4 shows cases in which the employment in the municipalities increased without controlling the abandonment of inhabitants. This occurs because job opportunities are mainly in the primary and secondary sectors. In these cases, the creation of employment in the tertiary sector reveals to be less relevant than in the other sectors. Data evidences that the development of primary or secondary sectors does not contribute to obviate the decline in inhabitants.

In contrast, a factor for the success of policies promoting local employment is the resilience of each municipality in adapting activities of the primary and secondary sectors into that of the tertiary sector.

(Insert Table 4 here)

A policy of exemption or reduction in the rate of an extra tax that is added to the central government's business income tax, which is in the purview of local governments, retains economic activity in rural municipalities. This is evidenced in Carrazeda de Ansiães, Oleiros, Almeida, Vila Velha de Rodão and Fronteira that have less than 10 thousand inhabitants (Figure 4).

(Insert Figure 4 here)

4. General shrinkage perceptions and policy results

4.1. Overall shrinkage perceptions

In general, from the subset of municipalities with a severe population decline, it can be stated that local governments have been implementing some strategy to deal with the phenomenon. The adopted strategies are not sufficient to invert the decline in population of those municipalities. Moreover, the identified strategies are mainly toward the development of smart growth practices, as predicted in the literature. Only in four of the 35 municipalities with 
severe population decline, it is not clear whether the local governments have implemented any one of the studied strategies. When we consider the 121 shrinking municipalities, only $8.2 \%$ of the municipalities have not implemented any of the analysed policies. This result reveals that the local entities that are confronted with high decrease in population recognize the situation and try to implement some strategy. Only a small number of municipalities have accepted shrinkage as inevitable and engaged smart shrinkage strategies. Thus, we can state that shrinkage remains a taboo for the majority of the Portuguese municipalities that face this persistent phenomenon.

Focussing on the 37 municipalities that face a more recent process of population decline, i.e., population loss in the last five years, a public intervention process dealing with population decline was not identified. This can be either because of the fact that the actions taken by the local governments have not received the attention of news agencies or the misperception of the symptoms of the problem by local governments causing their inaction to deal with the population decline problem.

Further research on this topic is required to confirm the underlying behaviour of such local governments. One reason for government inaction might be the reduced visibility of the phenomenon when it is at the initial stage. In fact, from this subset of municipalities, only three municipalities are already confronted with a decrease in the number of secondary students and only 15 municipalities are facing a reduction in the number of elderly inhabitants. However, the other natural symptoms of shrinkage are already felt in the majority of those municipalities: the number of marriages has decreased in 30 and the real estate value has fallen in 15. Employment in municipalities with a recent decline in population has not reacted in the same way. Only few municipalities have already begun to lose jobs and, in those cases, mainly because of significant employment contraction in the primary and secondary sectors. 


\subsection{Cases of shrinkage reversion}

During 1999-2008, in the Portuguese mainland only two municipalities have showed a period of population loss followed by a population increase: Tarouca and Alcobaça. Given this special situation, these municipalities deserve some attention. Tarouca is a small municipality in the rural part of the northern region with approximately 8 thousand inhabitants and Alcobaça, in the central region, is a medium-sized municipality with approximately 56 thousand inhabitants. Figure 5 shows their geographic position and gives a general picture of the village and the city where the municipal chambers are located.

\section{(Insert Figure 5 here)}

We do not find evidence to suggest these municipalities are using policies toward the increase of marriage, health service or employment numbers. However, evidence of an increasing enrolment of students is found, which suggests a policy of attracting young people and their families. This policy has succeeded in attracting new inhabitants. Table 5 summarises the major information regarding these municipalities.

\section{(Insert Table 5 here)}

Tarouca has a particular situation because it benefits from the fact that four of the five neighbouring municipalities do not have secondary schools. As such, the increase in the number of students is a result of the lack of other secondary schools nearby. Moreover, agriculture remains the most important activity here. Although the number of residents has evolved positively it is not a sustainable evolution as the municipality is located in the interior part of the country and is surrounded by shrinking municipalities.

The attraction of an increasing number of students to the municipality of Alcobaça is a combination of two factors: some of the secondary schools are positioned at the highest ranked score of the region and the emergence of new building projects. The schools of the municipality have achieved the top 20 national ranking in the disciplines of biology, history, 
and physics. Thus, more than quantity, quality here has been the driving force in attracting more students. This result is in line with the predictions of Nechyba and Strauss (1998), Black (1999), Carlsen (2001) and Bayer et al. (2004) on school quality being a determinant for household movement.

Moreover, the municipality is changing its development profile by increasing the relevance of the tertiary sector that has increased from $74.5 \%$ of the employment in 2003 to $81.3 \%$ in 2008 . Tourism and related commerce, namely of manufacture of pottery, ceramics, wicker, reeds, handkerchiefs, towels, rugs and tableware ensure the majority of employment. As the city has a monastery and a castle, it makes the municipality attractive for those who like cultural tourism.

The success of Alcobaça is thus a result of the economic conversion from activities of primary and secondary sectors into activities of the tertiary sector combined with the improvement of the quality of its secondary schools. However, Alcobaça benefits from some particular circumstances, such as the existence of heritage that is combined with a privileged location of being near the coast and surrounded by several growing municipalities, with the exception of Nazaré.

\subsection{Implications of the absence of a regional policy}

The majority of the municipalities facing a persistent process of population decline have been implementing at least one policy of promoting growth, i.e., oriented to recapture inhabitants. Those policies either promoted by local or central governments are isolated actions, lacking an integrated approach and requiring problem management at the regional level. The absence of an inter-municipal perspective of the problem might lead to the cancellation of the effects of the strategies followed by a certain municipality by the strategies adopted by neighbouring municipalities. These negative consequences tend to oversize the accumulation of local public deficits. Bartl (2009) had also found a similar result for Germany and Poland. To deal with this 
problem Domhardt and Troeger-Weiß (2009) propose, for the German case, "Municipal strategies must be supported by complementary regional planning that initiates and implements cooperative solutions." Without such an integrated approach in dealing with population decline, some municipalities will permanently lose population at the expense of others that are expanding.

The data reveals that this is particularly burdensome for the cases of Lisbon, Porto, and Espinho that are surrounded by expanding municipalities (Figure 6). The shrinkage of those municipalities generates a spillover effect to neighbouring municipalities, which stimulates urban sprawl policies. While Lisbon lost $16.6 \%$ of its residents in 10 years corresponding to a loss of 97200 inhabitants, Sintra a neighbouring municipality gained $29.2 \%$, corresponding to more than 100000 inhabitants. The same happened with Oporto, the second most important municipality and city of Portugal, which registered a loss of almost $20 \%$ of its population in a decade, the highest relative loss in the country. In contrast, the municipality of Vila Nova de Gaia, its neighbour, observed an increase of $12.6 \%$ of inhabitants. This is due to the fact that the average prices of houses are lower in neighbouring municipalities (in 2008, the price was 43\% lower in Sintra than in Lisbon and 50\% lower in Vila Nova de Gaia than in Oporto).

\section{(Insert Figure 6 here)}

The problem of differential house price occurs because, as referred by a Portuguese Business Journal (Jornal de Negócios, 2011), for Lisbon, one in each five buildings is either abandoned or in poor storage condition, totalling more than 54 thousand houses (dwellings), of which $78 \%$ are in ruins and the rest are abandoned. This observation emphasizes that a solution cannot be found at the municipal level but can be found by involving all neighbouring municipalities that compose the metropolitan area.

There is now an innovative project in the municipality of Lisbon, which is in the public discussion phase, through which the municipality intends to compel the owners of vacant 
buildings to provide for their rehabilitation. However, the problem remains to be tackled at the municipal level. A collective solution is difficult to implement because some neighbouring municipalities are expanding. This generates a competition with the neighbouring municipalities that formulate policies that are demographically advantageous in their favour.

\section{Conclusions}

Declining population is a pertinent topic of research. This paper systematises the most relevant policies taken by governments in Portugal to deal with the shrinkage phenomenon and evaluates their success.

The identified policies do not generally produce a change in the status quo. The analysed smart growth policies aiming to reverse municipal shrinkage, such as those oriented toward increasing the number of young people living in the municipality, by promoting marriage or attracting students, are ineffective if they are not accompanied by an increase in job opportunities. A positively discriminating fiscal policy for the development of economic activity in rural municipalities gives some transitory results, even though it does not solve the problem of declining population.

We have identified only one case of the municipality of Alcobaça where the population decline has been reversed in a sustainable way. As predicted in our hypothesis one, the main driving force for change was the resilience of the municipality in adapting the activities of the primary and secondary sectors into that of the tertiary sector. The economic conversion to more appealing sectors, accompanied by improvement of the quality of secondary schools, without increasing real estate value, provided the solution to the problem.

A relevant result of this paper is that the majority of local governments choose policies that favour growth, in accordance with our hypothesis two. Only a few local governments that face a permanent population decline, which mainly adopt isolated strategies to control the process, 
accept the problem, confirming our hypothesis three. Local governments see the maintenance of health care services as an anchor for obviating the abandonment of inhabitants and as a guaranty of life quality for those that choose to remain.

The absence of any national or regional policy to deal with the increasing abandonment of a territory does not help in defining an effective strategy to overcome the shrinkage. The lack of a more broad approach condemns almost all policies toward failure.

Shrinking cities are a global phenomenon that will expand in the future whether it results from deindustrialization, suburbanization, or the transformation of the social structure. Planners and political leaders must continue to study the characteristics of shrinkage and develop methods to manage this decline in a planned and creative way that will sustain the quality of life of the remaining population.

\section{Acknowledgments:}

This article was partially funded by the Foundation for Science and Technology.

\section{References}

Bartl, W. (2009) Adapting to a changing world: Municipal response to declining population numbers. The Network of Institutes and Schools of Public Administration in Central and Eastern Europe. Paper presented at the 17th NISPAcee Annual Conference, May, Budva, Montenegro.

Bayer, P., Ferreira, F.V. and Mcmillan, R. (2004) Tiebout sorting, social multipliers, and the demand for school quality. NBER Working Paper 10871.

Beauregard, R.A. (2003) Aberrant cities: Urban population loss in the United States, 18201930. Urban Geography, 24(8), pp. 672-690. 
Black, S.E. (1999) Do better schools matter? Parental valuation of elementary education. The Quarterly Journal of Economics, May, pp. 577-599.

Blackwell, A.G. and Fox, R.K. (2004) Regional equity and smart growth: Opportunities for advancing social and economic justice in America, in FL: Funders Network for Smart Growth and Livable Communities (ed.) Coral Gables. Available at: http://www.fundersnetwork.org/.

Caragliu, A., Del Bo, C. and Nijkamp, P. (2009) Smart cities in Europe. Serie Research Memoranda 0048 VU University Amsterdam, Faculty of Economics, Business Administration and Econometrics, Amsterdam.

Carlsen, F. (2001) Migration, local fiscal variables and local economic conditions. CESifo, Working Paper 553.

Carlsen, F., Langset, B., Rattso, J. and Stambol, L. (2009) Using survey data to study capitalization of local public services. Regional Science and Urban Economics, 39, pp. 688-695.

Daniels, T.L. (2001) Smart growth: A new American approach to regional planning. Planning Practice \& Research, 16, pp. 271-281.

Domhardt, H.J. and Troeger-Weiß, G. (2009) Germany's shrinkage on a small town scale, in K. Pallagst, J. Aber, I. Audirac, E. Cunningham-Sabot, S. Fol, C. Martinez-Fernandez, S. Moraes, H. Mulligan, J. Vargas-Hernandez, T. Wiechmann, T. Wu (Eds) The future of shrinking cities: Problems, patterns and strategies of urban transformation in a global context, Center for Global Metropolitan Studies, Institute of Urban and Regional Development and the Shrinking Cities International Research Network, University of California - Berkeley, pp. 161-168.

Downs, A. (2001) What does "smart growth" really mean? Planning, 67, pp. 20-26.

Frank, P. (2004) Shrinking cities - Shrinking economy? The case of East Germany. German Journal of Urban Studies, 43(1). 
Gabriel, S.A., Faria, J.A. and Moglen, G.E. (2006) A multiobjective optimization approach to smart growth in land development. Socio-Economic Planning Sciences, 40, pp. 212-248.

Glaeser, E.L. and Gyourko, J. (2005) Urban decline and durable housing. The Journal of Political Economy, 113, pp. 345-375.

Glock, B. and Häußermann, H. (2004) New trends in urban development and public policy in eastern Germany: Dealing with the vacant housing problem at the local level. International Journal of Urban and Regional Research 28(4), pp.919-929.

Grant, J.L. (2009) Theory and practice in planning the suburbs: Challenges to implementing new urbanism, smart growth, and sustainable principles. Planning Theory \& Practice, 10(1), pp. $11-33$.

Großmann, K., Haase, A., Rink, D. And Steinführer, A. (2008), Urban shrinkage in East central Europe? Benefits and limits of a cross-national transfer of research approaches, in Nowak, M. and Nowosielski, M. (Eds), Declining cities/Developing cities: Polish and German perspectives, Instytut Zachodni, Poznän, pp.77-99.

Jornal de Negócios (2011) Lisbon has more than 20\% of buildings in ruins or abandoned (Lisboa tem mais de $20 \%$ dos edifícios em ruínas ou abandonados). Economic Section, March 23, pp. 34.

Koziol M. (2004) The consequences of demographic change for municipal infrastructure. German Journal of Urban Studies, 43(1).

Lange, B. (2008) Reconfiguring Europe: Expert knowledge, EU-projects, and the formation of "creative cities", in Nowak, M. and Nowosielski, M. (Eds), Declining cities/Developing cities: Polish and German perspectives, Instytut Zachodni, Poznän, pp.3-30.

Lötscher, L., Howest, F. and Basten, L. (2004) Eisenhüttenstadt: Monitoring a shrinking German city. Univerza v Ljubljani, Della 21. 
Lovering, J. (2009) Fordism, Post-Fordism and Flexible Specialization. International Encyclopedia of Human Geography, pp. 232-242.

Mading, H. (2004) Demographic change and local government finance - Trends and expectations. German Journal of Urban Studies, 43(1).

Muller, B. and Siedentop, S. (2004) Growth and shrinkage in Germany - Trends, perspectives and challenges for spatial planning and development. German Journal of Urban Studies, 43(1).

Nechyba, T.J. and Strauss, R.P. (1998) Community choice and local public services: A discrete choice approach. Regional Science and Urban Economics, 28, pp. 51-73.

Oswald, P. (2005) Shrinking cities - Volume 1: International Research. Germany: Hatje Verlag.

Pallagst, K. (2008) Shrinking cities: Planning challenges from an international perspective, in Rugare, S. and Schwarz, T. (Ed.) Cities Regrowing Smaller, Urban Infill book series, Cleveland, pp. 6-16.

Pallagst, K., Schwarz, T., Popper, F.J. and Hollander, J.B. (2009) Planning shrinking cities. Progress in Planning, 72(4), pp. 223-232.

Popper, D.E., Popper, F.J. 2002. Small Can Be Beautiful: Coming to Terms with Decline, Planning, 68(7), pp. 20-23.

Rink, D., Haase, A. and Bernt, M. (2009) Specification of working model. Shrink Smart - The Governance of Shrinkage within a European Context. Workpackage 1.

Rybczynski, W. and Linneman, P.D. (1999) How to save our shrinking cities. Public Interest, spring, pp. 30-44.

Schilling, J. (2008) Buffalo as the nation's first living laboratory for reclaiming vacant properties, in Rugare, S. and Schwarz, T. (Ed.), Cities Regrowing Smaller, Urban Infill book series, Cleveland, pp. 31-43. 
Schwarz, T. (2008) The Cleveland land lab: experiments for a city in transition, in Rugare, S. and Schwarz, T. (Ed.) Cities Regrowing Smaller, Urban Infill book series, Cleveland, pp. 71-83.

Sedlacek, P. (2007) Kommunale Bevölkerungspolitik - Ein Weg aus der Krise? in P. Sedlacek (Ed.), Umdenken Umplanen Umbauen. Stadt- und Regionalentwicklung in Sachsen, SachsenAnhalt und Thüringen unter Schrumpfungsbedingungen. Arbeitsmaterial, Verlag der ARL, Hannover.

Shapiro, J.M. (2006) Smart Cities: Quality of life, productivity, and the growth effects of human capital. Review of Economics and Statistics, 88, pp. 324-335.

Shrinksmart (2009) Project title: SHRINK SMART - The Governance of Shrinkage within a European Context. Collaborative research project funded by the 7th Framework Programme/ Socio-economic Sciences and Humanities of the EC, Project number: 225193, Duration: 05/2009-04/2012. Available at: http://www.shrinksmart.ufz.de/.

Swope, C. (2006) Smart decline. Governing. Available at: http://www.governing.com/mag/November-2006.html.

Szold, T.S. and Carbonell, A. (Eds) (2002) Smart growth form and consequences. Lincoln Institute of Land Policy, Ontario.

United Nations Secretariat (2008) World Population Prospects Database: The 2008 revision. Population Division of the Department of Economic and Social Affairs. Available at: http://esa.un.org/unpp/.

Van den Berg, L., Drewett, R., Klaasen, L.H., Rossi, A. and Vijverberg, C.H.T. (1982) Urban Europe: A Study of Growth and Decline. Pergamon Press, Oxford.

Wiechmann, T. (2008) Strategic flexibility beyond growth and shrinkage: Lessons from Dresden, Germany, in Rugare, S. and Schwarz, T. (Ed.) Cities Regrowing Smaller, Urban Infill book series, Cleveland, pp. 17-29. 
Figure 1 - Territorial evolution of the population
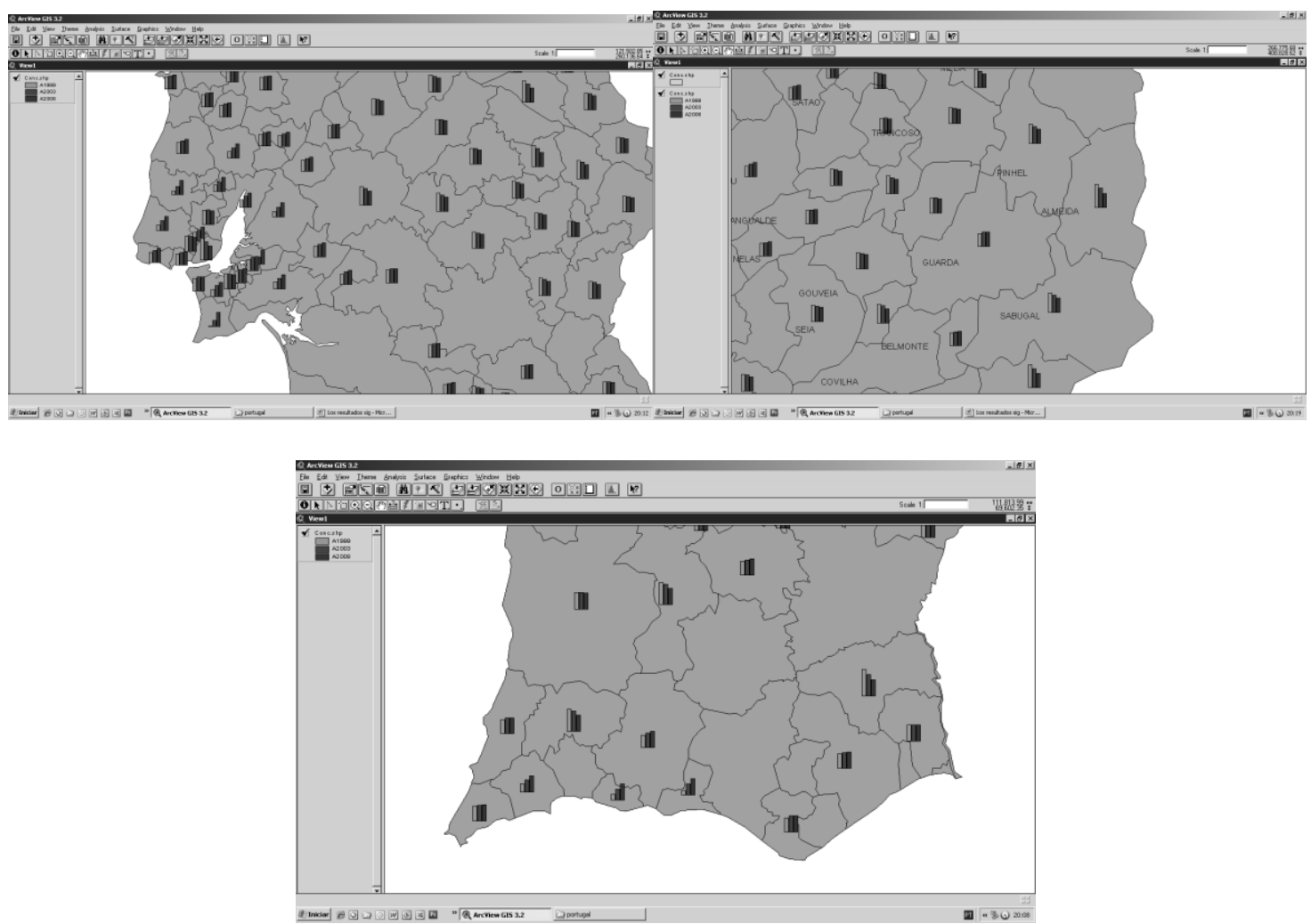

Source: Portuguese National Statistics (I.N.E) - Annual Regional Statistics and own calculations.

Figure 2 - Demographic dynamics in Portugal
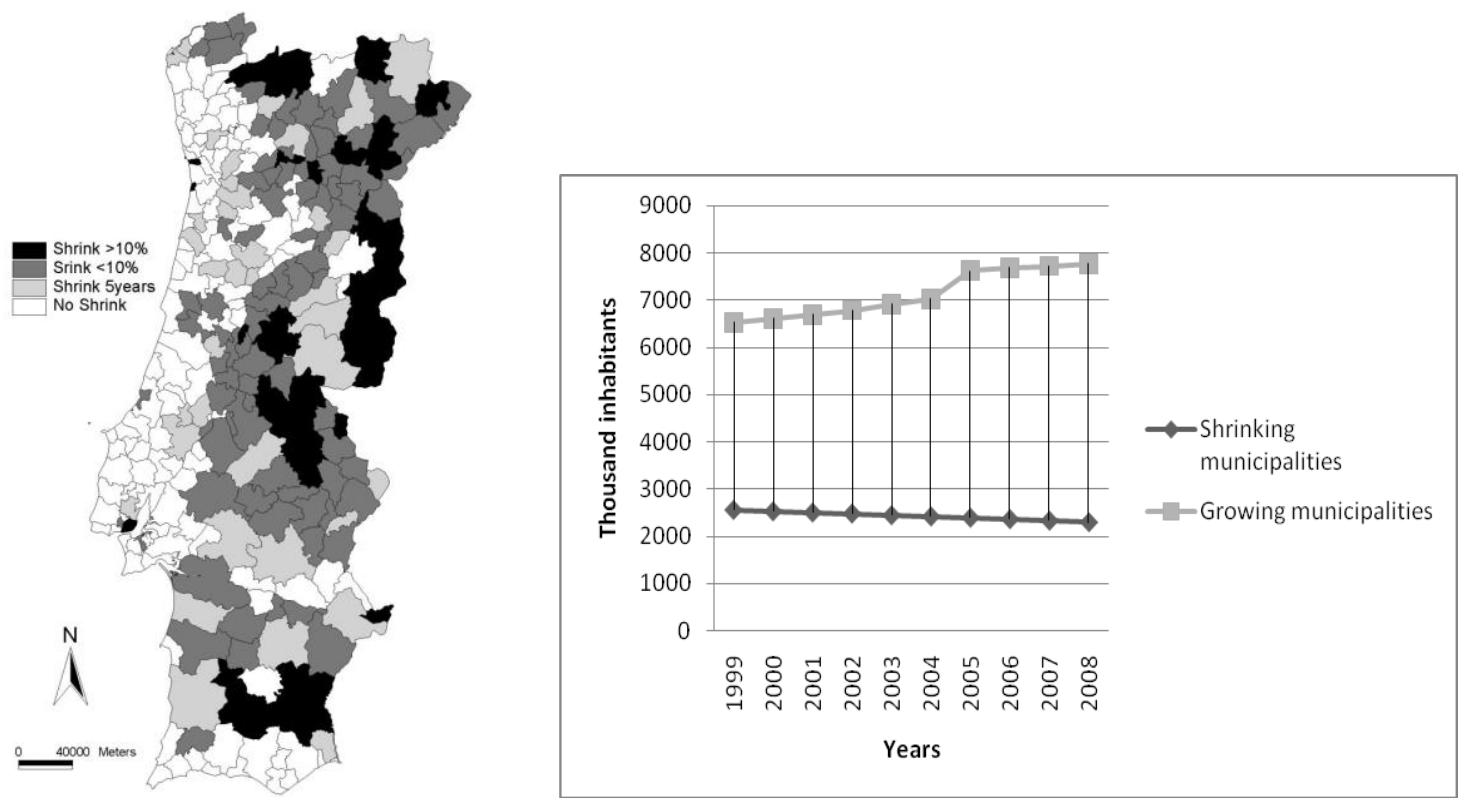

Source: Portuguese National Statistics (I.N.E) - Annual Regional Statistics and own calculations. 
Table 1 - Municipalities with decline in inhabitants and strategies promoting marriage

\begin{tabular}{|l|c|c|c|c|c|c|}
\cline { 2 - 7 } & \multicolumn{2}{|c|}{$\begin{array}{c}\text { Variation in the number of } \\
\text { inhabitants }\end{array}$} & \multicolumn{2}{c|}{$\begin{array}{c}\text { Variation in the number of } \\
\text { marriages }\end{array}$} & \multicolumn{2}{c|}{$\begin{array}{c}\text { Variation in the number of } \\
\text { births }\end{array}$} \\
\cline { 2 - 7 } & $\mathbf{1 9 9 9 / 2 0 0 3}$ & $\mathbf{2 0 0 4 / 2 0 0 8}$ & $\mathbf{1 9 9 9 / 2 0 0 3}$ & $\mathbf{2 0 0 4 / 2 0 0 8}$ & $\mathbf{1 9 9 9 / 2 0 0 3}$ & $\mathbf{2 0 0 4 / 2 0 0 8}$ \\
\hline Porto & -9.04 & -9.57 & -28.11 & 11.32 & -20.75 & -7.70 \\
\hline Boticas & -7.26 & -6.21 & -16.67 & 46.67 & -13.95 & -34.88 \\
\hline Vinhais & -7.07 & -6.60 & -26.98 & 10.00 & -28.79 & -12.24 \\
\hline Almeida & -7.92 & -9.88 & 38.10 & 22.73 & -30.36 & -38.30 \\
\hline Lisboa & -7.97 & -7.54 & -35.15 & 17.49 & 2.21 & 6.58 \\
\hline Marvão & -5.57 & -6.69 & -37.50 & 42.86 & 25.00 & -66.67 \\
\hline Ourique & -3.16 & -7.12 & 17.39 & 75.00 & 11.11 & -46.15 \\
\hline Alcoutim & -8.66 & -9.00 & -26.67 & 228.57 & -31.58 & 0.00 \\
\hline
\end{tabular}

\begin{tabular}{|l|c|c|c|c|c|c|}
\cline { 2 - 7 } & \multicolumn{2}{|c|}{$\begin{array}{c}\text { Variation in employment in the } \\
\text { establishments of the } \\
\text { municipality }\end{array}$} & \multicolumn{2}{c|}{$\begin{array}{c}\text { Variation in employment in } \\
\text { the primary sector }\end{array}$} & \multicolumn{2}{c|}{$\begin{array}{c}\text { Variation in employment in } \\
\text { the secondary sector }\end{array}$} \\
\cline { 2 - 7 } & $\mathbf{1 9 9 9 / 2 0 0 3}$ & $\mathbf{2 0 0 4 / 2 0 0 8}$ & $\mathbf{1 9 9 9 / 2 0 0 3}$ & $\mathbf{2 0 0 4 / 2 0 0 8}$ & $\mathbf{1 9 9 9 / 2 0 0 3}$ & $\mathbf{2 0 0 4 / 2 0 0 8}$ \\
\hline Porto & -13.18 & 5.48 & 1.85 & -12.26 & -28.34 & -9.54 \\
\hline Boticas & 6.37 & -7.60 & -90.91 & n.a. & -25.98 & n.a. \\
\hline Vinhais & 27.20 & -2.52 & 0.00 & -100.00 & 24.42 & 11.69 \\
\hline Almeida & 20.37 & 5.74 & 107.14 & 16.67 & 88.03 & -13.37 \\
\hline Lisboa & -5.20 & 5.60 & -22.26 & -34.07 & -18.87 & -18.14 \\
\hline Marvão & -12.30 & n.a. & -35.71 & n.a. & -28.81 & n.a. \\
\hline Ourique & 17.47 & 0.62 & -6.93 & 15.84 & 18.80 & -29.73 \\
\hline Alcoutim & 29.81 & n.a. & 1200.00 & n.a. & 12.07 & 17.72 \\
\hline
\end{tabular}


Figure 3 - Policies promoting marriage

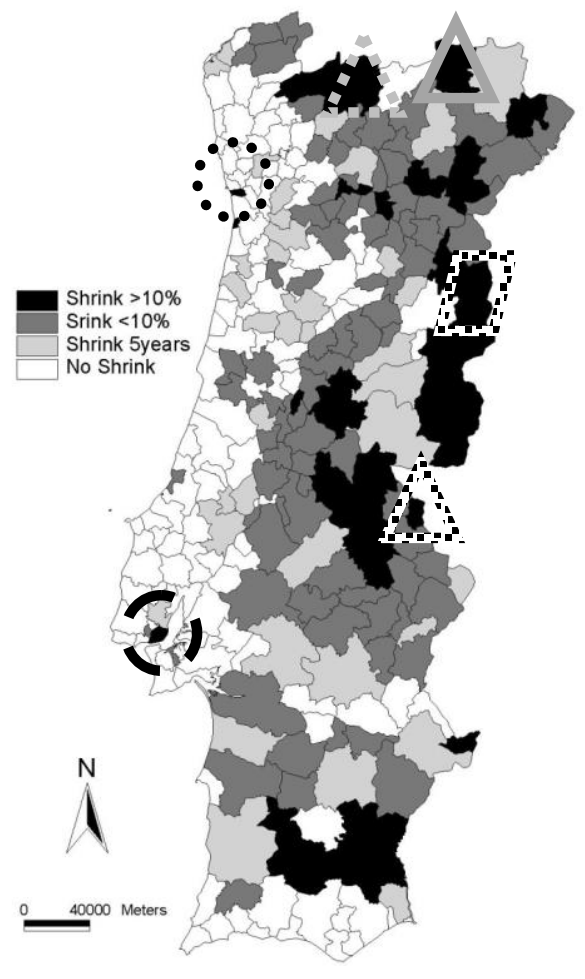

Legend:

Clisbon and $\stackrel{\because}{ }$ :. Oporto: real estate valuation forces households to search for houses in neighbouring municipalities, despite the availability of job opportunities.

Boticas, $\triangle$ Vinhais and not generate employment.

Almeida faces a change in its employment profile: industrial employment is in decline, the major number of jobs offered is in the primary sector, which is often a seasonal activity, and thus it does not ensure permanent residence.

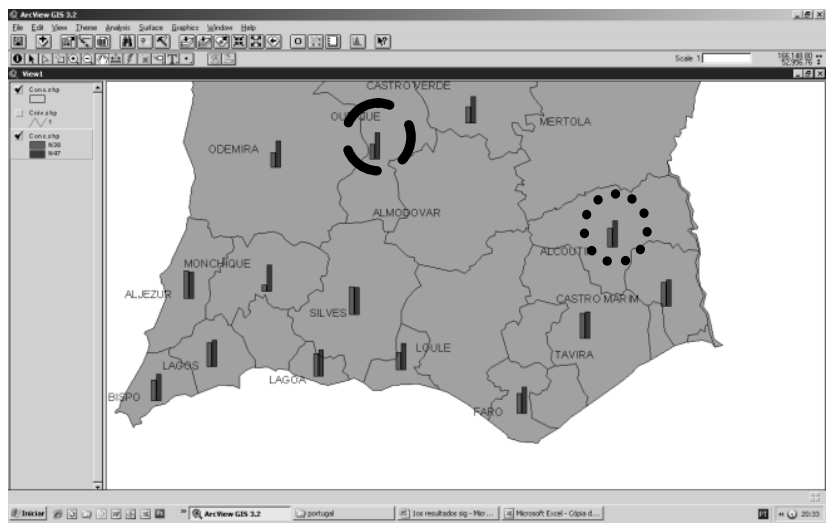

$\because \because$ Alcoutim and Sourique were not able to increase birth rate due the lack of jobs opportunities.

Source: Portuguese National Statistics (I.N.E) - Annual Regional Statistics and own calculations. 
Table 2 - Municipalities with decline in inhabitants and strategies promoting education

\begin{tabular}{|c|c|c|c|c|c|c|}
\hline & \multicolumn{2}{|c|}{$\begin{array}{l}\text { Variation in the number of } \\
\text { inhabitants }\end{array}$} & \multicolumn{2}{|c|}{$\begin{array}{l}\text { Variation in secondary } \\
\text { school students }\end{array}$} & \multicolumn{2}{|c|}{$\begin{array}{c}\text { Variation in employment in } \\
\text { the establishments of the } \\
\text { municipality }\end{array}$} \\
\hline & $1999 / 2003$ & $2004 / 2008$ & $1999 / 2003$ & $2004 / 2008$ & $1999 / 2003$ & $2004 / 2008$ \\
\hline Terras de Bouro & -5.42 & -5.64 & 55.17 & 25.56 & 5.48 & -16.40 \\
\hline Espinho & -4.06 & -7.01 & 6.63 & 9.78 & -18.53 & n.a. \\
\hline Porto & -9.04 & -9.57 & 1.46 & 49.16 & -13.18 & 5.48 \\
\hline Mesão Frio & -5.56 & -6.34 & -20.98 & 16.95 & 54.74 & -15.38 \\
\hline Peso da Régua & -5.67 & -5.53 & -5.61 & 17.85 & 7.99 & -3.89 \\
\hline Tabuaço & -5.67 & -4.57 & -5.04 & 35.04 & -14.58 & 19.82 \\
\hline Mação & -8.71 & -9.04 & -35.06 & 76.34 & 22.62 & -0.17 \\
\hline Idanha-a-Nova & -6.97 & -7.16 & 67.80 & 58.45 & 16.54 & -24.46 \\
\hline Lisboa & -7.97 & -7.54 & -1.13 & 39.97 & -5.20 & 5.60 \\
\hline
\end{tabular}

Table 3 - Municipalities with decline in inhabitants and strategies promoting health care maintenance

\begin{tabular}{|c|c|c|c|c|c|c|}
\hline & \multicolumn{2}{|c|}{$\begin{array}{l}\text { Variation in the number } \\
\text { of inhabitants }\end{array}$} & \multicolumn{2}{|c|}{$\begin{array}{l}\text { Variation in the number of } \\
\text { doctors per thousand } \\
\text { inhabitants }\end{array}$} & \multicolumn{2}{|c|}{$\begin{array}{c}\text { Variation in employment in } \\
\text { the establishments of the } \\
\text { municipality }\end{array}$} \\
\hline & $1999 / 2003$ & $2004 / 2008$ & $1999 / 2003$ & $2004 / 2008$ & $1999 / 2003$ & $2004 / 2008$ \\
\hline Carrazeda de Ansiães & -7.11 & -6.59 & -30.55 & 29.96 & 45.71 & 24.76 \\
\hline Tabuaço & -5.67 & -4.57 & -42.74 & 95.03 & -14.58 & 19.82 \\
\hline Torre de Moncorvo & -4.83 & -6.15 & -2.20 & 4.53 & 12.77 & -11.81 \\
\hline Alfândega da Fé & -5.07 & -5.63 & -2.29 & 21.89 & 1.87 & 11.54 \\
\hline Boticas & -7.26 & -6.21 & 20.53 & 37.61 & 6.37 & -7.60 \\
\hline Montalegre & -6.48 & -6.16 & 10.20 & 41.75 & 27.07 & -3.61 \\
\hline Vinhais & -7.07 & -6.60 & 8.17 & 20.61 & 27.20 & -2.52 \\
\hline Almeida & -7.92 & -9.88 & 12.29 & 38.38 & 20.37 & 5.74 \\
\hline Alcoutim & -8.66 & -9.00 & 16.31 & 29.62 & 29.81 & n.a. \\
\hline
\end{tabular}

Source: Portuguese National Statistics (I.N.E) - Annual Regional Statistics and own calculations. 
Table 4 - Municipalities with decline in inhabitants and strategies promoting employment

\begin{tabular}{|l|c|c|c|c|}
\cline { 2 - 5 } \multicolumn{1}{c|}{} & \multicolumn{2}{c|}{$\begin{array}{c}\text { Variation in the number of } \\
\text { inhabitants }\end{array}$} & $\begin{array}{c}\text { Variation in employment in } \\
\text { the establishments of the } \\
\text { municipality }\end{array}$ \\
\cline { 2 - 5 } \multicolumn{1}{c|}{} & $1999 / 2003$ & $\mathbf{2 0 0 4 / 2 0 0 8}$ & $1999 / 2003$ & $\mathbf{2 0 0 4 / 2 0 0 8}$ \\
\hline Carrazeda de Ansiäes & -7.11 & -6.59 & 45.71 & 24.76 \\
\hline Tabuaço & -5.67 & -4.57 & -14.58 & 19.82 \\
\hline Alfândega da Fé & -5.07 & -5.63 & 1.87 & 11.54 \\
\hline Oleiros & -7.23 & -7.37 & -2.83 & 16.60 \\
\hline Almeida & -7.92 & -9.88 & 20.37 & 5.74 \\
\hline Vila Velha de Ródão & -7.83 & -9.26 & -2.35 & 12.02 \\
\hline Fronteira & -6.29 & -7.66 & 12.28 & 11.13 \\
\hline Barrancos & -3.56 & -7.01 & 82.22 & 22.56 \\
\hline Ourique & -3.16 & -7.12 & 17.47 & 0.62 \\
\hline
\end{tabular}

\begin{tabular}{|l|c|c|c|c|c|c|}
\cline { 2 - 7 } & \multicolumn{2}{c|}{$\begin{array}{c}\text { Variation in employment in the } \\
\text { primary sector }\end{array}$} & \multicolumn{2}{c|}{$\begin{array}{c}\text { Variation in employment in } \\
\text { the secondary sector }\end{array}$} & \multicolumn{2}{c|}{$\begin{array}{c}\text { Variation in employment in } \\
\text { the tertiary sector }\end{array}$} \\
\cline { 2 - 7 } & $\mathbf{1 9 9 9 / 2 0 0 3}$ & $\mathbf{2 0 0 4 / 2 0 0 8}$ & $\mathbf{1 9 9 9 / 2 0 0 3}$ & $\mathbf{2 0 0 4 / 2 0 0 8}$ & $\mathbf{1 9 9 9 / 2 0 0 3}$ & $\mathbf{2 0 0 4 / 2 0 0 8}$ \\
\hline Carrazeda de Ansiães & -47.37 & 38.71 & 46.91 & 17.48 & 67.08 & 25.86 \\
\hline Tabuaço & -52.53 & -3.80 & -16.75 & 30.90 & 17.56 & 19.23 \\
\hline Alfândega da Fé & -81.25 & 84.38 & 42.47 & -2.42 & 0.00 & 9.44 \\
\hline Oleiros & -14.29 & 3.70 & -9.22 & 21.27 & 9.13 & 11.19 \\
\hline Almeida & 107.14 & 16.67 & 88.03 & -13.37 & 5.87 & 10.12 \\
\hline Vila Velha de Ródão & -42.11 & 8.00 & -14.59 & 15.44 & 36.21 & 8.37 \\
\hline Fronteira & -22.22 & -27.84 & 28.24 & 64.08 & 31.58 & 16.36 \\
\hline Barrancos & 15.79 & 15.15 & 139.29 & 37.50 & 74.42 & 16.98 \\
\hline Ourique & -6.93 & 15.84 & 18.80 & -29.73 & 24.51 & 14.57 \\
\hline
\end{tabular}

Source: Portuguese National Statistics (I.N.E) - Annual Regional Statistics and own calculations. 
Figure 4-Policies promoting employment

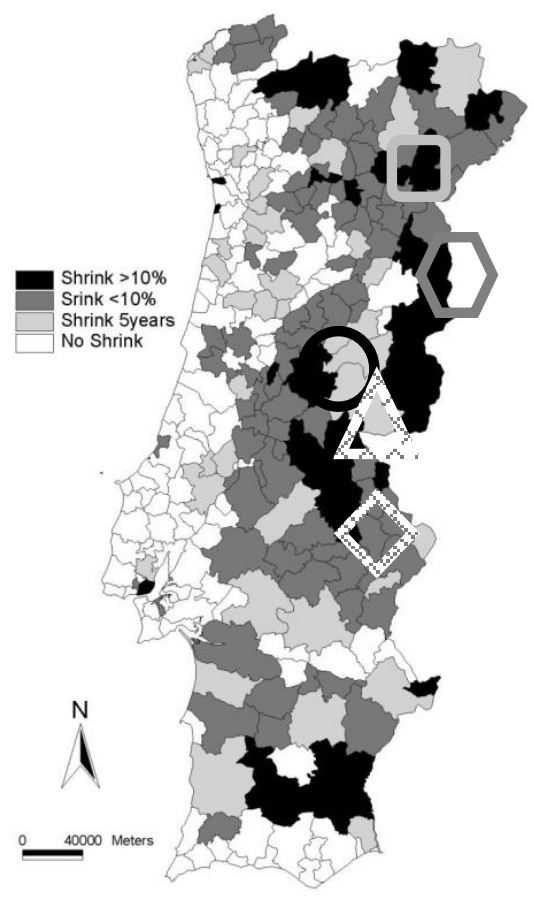

Legend:

Carrazeda de Ansiães

Oleiros

Almeida

Vila Velha de Rodão

Fronteira

Source: Portuguese National Statistics (I.N.E) - Annual Regional Statistics and own calculations. 
Figure 5 - Perspective and location of Tarouca village and Alcobaça city
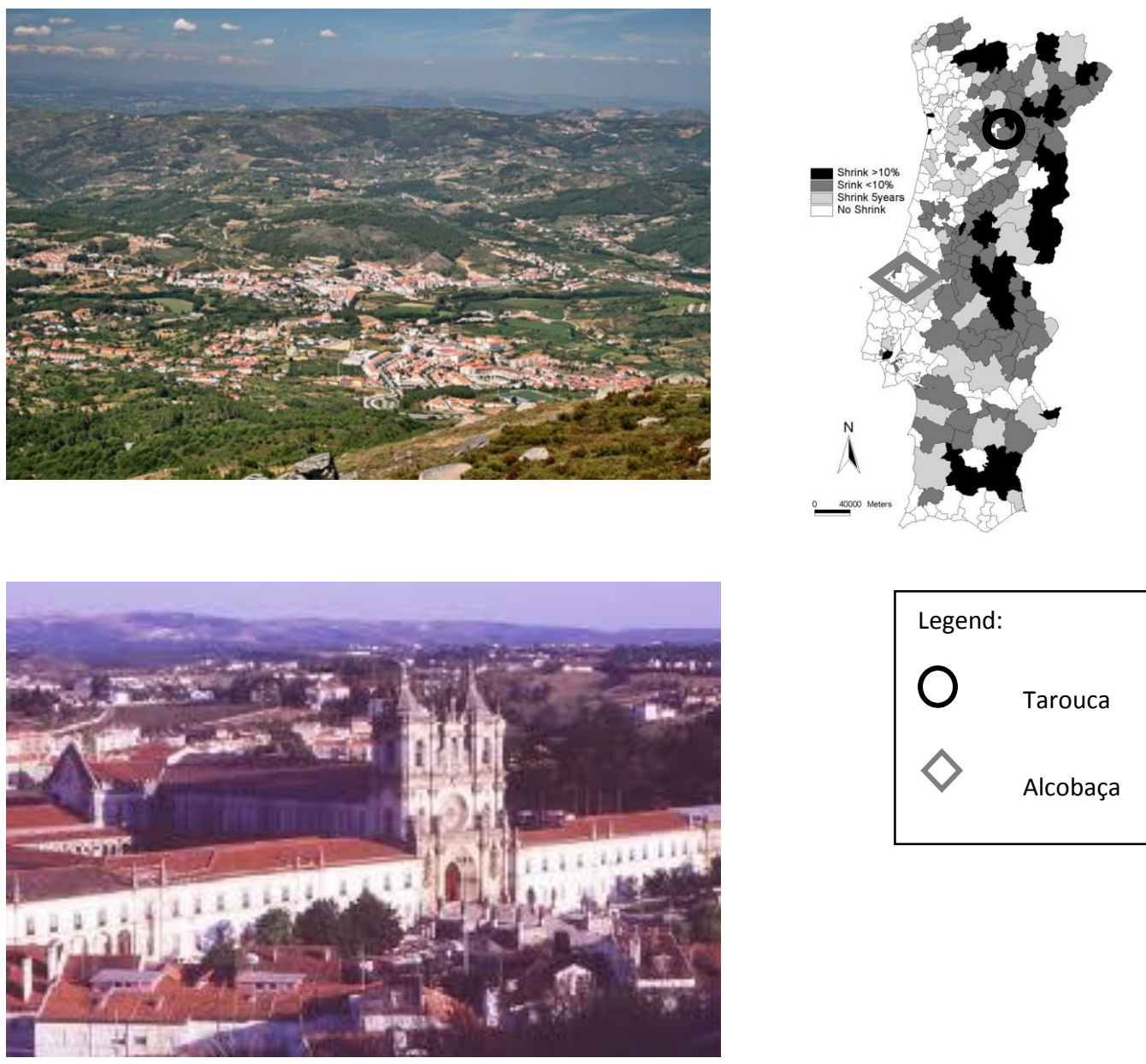
Table 5 - Municipalities with decline in inhabitants and reversing process

\begin{tabular}{|c|c|c|c|c|c|c|}
\cline { 2 - 7 } & \multicolumn{2}{c|}{$\begin{array}{c}\text { Variation in the number of } \\
\text { inhabitants }\end{array}$} & \multicolumn{2}{c|}{$\begin{array}{c}\text { Variation in inhabitants <15 } \\
\text { years }\end{array}$} & \multicolumn{2}{c|}{$\begin{array}{c}\text { Variation in inhabitants }>65 \\
\text { years }\end{array}$} \\
\cline { 2 - 7 } & $1999 / 2003$ & $2004 / 2008$ & $1999 / 2003$ & $2004 / 2008$ & $1999 / 2003$ & $2004 / 2008$ \\
\hline Tarouca & -2.36 & 0.24 & -20.91 & -8.36 & -11.89 & 3.75 \\
\hline Alcobaça & -0.72 & 0.67 & -7.55 & -2.87 & 10.25 & 3.88 \\
\hline
\end{tabular}

\begin{tabular}{|l|c|c|c|c|c|c|}
\cline { 2 - 7 } & \multicolumn{2}{c|}{$\begin{array}{c}\text { Variation in the number of } \\
\text { marriages }\end{array}$} & \multicolumn{2}{c|}{$\begin{array}{c}\text { Variation in the number of } \\
\text { secondary school students }\end{array}$} & $\begin{array}{c}\text { Variation in the real price of } \\
\text { houses }\end{array}$ \\
\cline { 2 - 7 } & $1999 / 2003$ & $2004 / 2008$ & $1999 / 2003$ & $2004 / 2008$ & $1999 / 2003$ & $2004 / 2008$ \\
\hline Tarouca & -32.76 & -8.51 & 37.06 & 22.39 & 64.75 & -38.62 \\
\hline Alcobaça & -44.15 & -17.48 & 2.26 & 33.52 & 26.63 & -7.06 \\
\hline
\end{tabular}

\begin{tabular}{|c|c|c|c|c|}
\cline { 2 - 5 } \multicolumn{1}{c|}{} & \multicolumn{2}{|c|}{$\begin{array}{c}\text { Variation in the number of } \\
\text { doctors per thousand } \\
\text { inhabitants }\end{array}$} & \multicolumn{2}{c|}{$\begin{array}{c}\text { Variation in employment in } \\
\text { the establishments of the } \\
\text { municipality }\end{array}$} \\
\cline { 2 - 5 } & $1999 / 2003$ & $2004 / 2008$ & $1999 / 2003$ & $2004 / 2008$ \\
\hline Tarouca & 27.92 & -5.11 & 93.08 & -14.57 \\
\hline Alcobaça & 15.90 & -0.52 & -9.35 & -7.71 \\
\hline
\end{tabular}

\begin{tabular}{|c|c|c|c|c|c|c|}
\cline { 2 - 7 } \multicolumn{1}{c|}{} & \multicolumn{2}{|c|}{$\begin{array}{c}\text { Variation in employment in } \\
\text { the primary sector }\end{array}$} & $\begin{array}{c}\text { Variation in employment in } \\
\text { the secondary sector }\end{array}$ & $\begin{array}{c}\text { Variation in employment in } \\
\text { the tertiary sector }\end{array}$ \\
\cline { 2 - 7 } \multicolumn{1}{c|}{} & $1999 / 2003$ & $2004 / 2008$ & $1999 / 2003$ & $2004 / 2008$ & $1999 / 2003$ & $2004 / 2008$ \\
\hline Tarouca & 9.30 & -23.40 & 45.89 & 7.27 & 156.70 & -26.45 \\
\hline Alcobaça & 21.32 & 2.46 & -25.53 & -17.09 & 35.11 & 5.56 \\
\hline
\end{tabular}

Source: Portuguese National Statistics (I.N.E) - Annual Regional Statistics and own calculations. 
Figure 6 - Spillover effects of shrinkage in the coastal municipalities

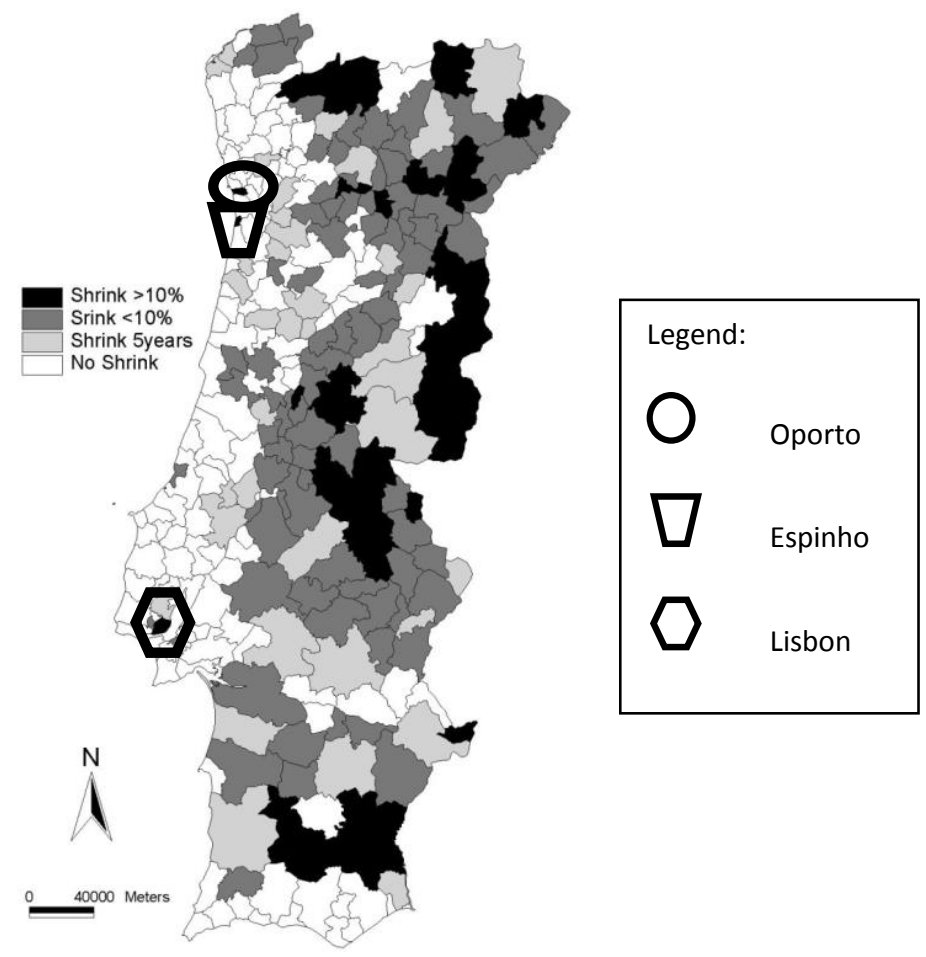

\footnotetext{
' Portugal is also composed of the archipelagos of the Azores and Madeira. These have an intermediate institutional level between the central and local governments constituting a regional government whose competences find no counterparts on the mainland, where there is no such intermediate level. They are not considered in this work.

ii In Portugal, there is another lower government level: the parish level, which is economically dependent on municipality transfers. There are around 4050 parishes on the Portuguese mainland.
} 